\title{
Effects of Treatment of Sorghum Stover Residue With Ammonium Hydroxide on Cell Wall Composition and in vitro Digestibility
}

\author{
Adnan B. Yousuf $^{1}$, A. Dismuke ${ }^{1}$, M. Kering ${ }^{1} \&$ A. Atalay ${ }^{1}$ \\ ${ }^{1}$ Agriculture Research Station, Virginia State University, Virginia, USA \\ Correspondence: Adnan B. Yousuf, Agriculture Research Station, Virginia State University, P. O. Box 9061, \\ Virginia 23806, USA. Tel: 1-804-524-6795. E-mail: ayousuf@vsu.edu
}

Received: June 5, 2014 Accepted: June 30, 2014 Online Published: August 15, 2014

doi:10.5539/jas.v6n9p21

URL: http://dx.doi.org/10.5539/jas.v6n9p21

\begin{abstract}
The study was undertaken to determine the effects of ammonium hydroxide $\left(\mathrm{NH}_{4} \mathrm{OH}\right)$ treatment of sorghum stover residue on composition and in vitro dry matter disappearance (IVDMD) of two sorghum varieties, Dale (tall, sweet sorghum variety) and Brown mid rib (BMR) (Short, grain sorghum variety). The residue was treated with; water only (T00), $50 \mathrm{~g} \mathrm{NH}_{4} \mathrm{OH} \mathrm{kg}^{-1}$ residue dry matter (DM) (T50), $100 \mathrm{~g} \mathrm{NH}_{4} \mathrm{OH} \mathrm{kg}^{-1} \mathrm{DM}$ (T100), and untreated control (neither water nor $\mathrm{NH}_{4} \mathrm{OH}$ ) (TUN) and allowed to react for one week before chemical analysis was performed. The fiber content (ADF and NDF) were not affected by the levels of alkali treatment but the crude protein $(\mathrm{CP})$ and Soluble protein contents were both increased by alkali treatment. There was an increase $(P<0.05)$ in dry matter digestibility in vitro (IVDMD) by $\mathrm{NH}_{4} \mathrm{OH}$ treatment from $529 \mathrm{~g} \mathrm{~kg}^{-1}$ to $651 \mathrm{~g} \mathrm{~kg}^{-1}$ in T50 and T100. The improvement in IVDMD may indicate that $\mathrm{NH}_{4} \mathrm{OH}$ helps disrupt the lignin-carbohydrate complexes. The development of more economical and safe procedures which improve digestibility of the structural cell wall components would be very beneficial for improving the use of crop residue as feedstock for livestock and bioethanol production.
\end{abstract}

Keywords: sorghum stover, ammonium hydroxide, alkali treatment, IVDMD

\section{Introduction}

Sorghum (Sorghum bicolor (L.) Moench), is a warm season grass that does well in a variety of soils and withstands hot and dry conditions. There are diverse species of sorghum that are grown for grain, biofuel, and forage. As a forage crop, most interest in sorghum has been concentrated on hybrid varieties, brown midrib genotypes, and sorghum-sudangrass (Houx III et al., 2013). This variety has distinct morphological characteristics including extensive root system, smaller leaf area with a waxy coating that limits water loss; it is the most widely adapted species among grasses for biomass and fuel production (Hons et al., 1986). The sweet sorghum varieties have been bred primarily for syrup production. Because of their high sugar content and large biomass yield, sweet sorghums have attracted the attention of researchers who have evaluated them as biofuel crops (Smith et al., 1987; Putnam et al., 1991; Rooney et al., 2007). If it is produced for biofuel, the acreage of sweet sorghum would likely increase. The sweet sorghum varieties tend to have higher yield, with lower lignin and higher digestibility than grain sorghums (Houx III et al., 2013). In the US, out of a total of 3.2 million hectares under sorghum in 2013, 2.6 million hectares were harvested for grain (USDA, 2014).

Unlike corn, sorghum continues to synthesize new vegetative material even after physiological maturity and its stover forage quality decreases at a lower rate (Bolsen et al., 1977). The left over residual material may have high lignin content and low forage quality, but its protein level is reported to remain above the minimum needed for gestating cow (Ward et al., 1979). In vitro dry matter disappearance (IVDMD) of sorghum stover was reported to be sufficient for cattle maintenance energy needs (Youngquist et al., 1990) and could offer maintenance energy to animals especially during period of forage deficits. Crop residues are poorly digested by ruminants because of their high cell-wall content. While forage sorghums can currently be grazed or hayed, residual stover from other sorghum types can be used as alternative hay source for animal.

The increasing global population will lead to increased demand for food and it is estimated that between 2003 and 2020, demand for livestock products will double (Delgado et al., 1999). To meet increased food demand with current agricultural land acreage, there is a need for new approaches on crop and livestock management strategies that include alternative forage sources. While genetic improvements may increase animal productivity, 
decreased availability of arable land may reduce acreage for forage production and lead to shortage of animal feed. Furthermore, increased erratic rainfall and drought incidences, production acreage of moisture stress tolerant crops like sorghum is likely to increase. Grain sorghum is produced for seed while sweet sorghums are produced to provide sugary juice for bioethanol plants. Both operations leave behind crop residual material that can be used for forage. Given current global climate-change prediction that paints a future dry and hot climate, these crops may be the choice of the future and therefore also a potential source of residual material for forage.

Meeting future animal forage demands will be challenging and alternative feed sources should be sought. One such alternative is crop residue; the non-edible plant parts that are left in the field after crops have been harvested and thrashed. Some researchers also include remains generated from crop-packing plants or that are discarded during crop processing (Ernest \& Buffington, 1981). Despite their low digestibility, metabolizable energy, and mineral element contents and generally low forage quality (Nicholson, 1984; Doyle et al., 1986), crop residues have provided alternative forage in many parts of the world.

The forage quality of plant residual materials can be improved by use of chemicals. The chemical treatment of straws and other crop residues can increase the digestibility of the material for ruminants (Klopfenstein, 1978); it can be accomplished through the use of either alkaline compounds (Waiss \& Guggolz, 1972; Rounds \& Klopfenstein, 1974; Sundstol, 1984; Mason et al., 1990a; Goto et al., 1993) or oxidizing compounds (Ben-Ghedalia et al., 1980; Ben-Ghedalia \& Miron, 1981; 1984; Bunting et al., 1984; Kerley et al., 1987; Amjed et al., 1992; Sultan et al., 1992).

The mode of action of alkaline compounds consists of a partial hydrolysis of the cell wall, which ruptures the ester bonds between hemicellulose and lignin without removing the latter (Jackson, 1977; Klopfenstein, 1978). Treatments with alkaline chemicals diesterifies lignin and xylan to release cellulose and hemicellulose and make them available for enzymatic breakdown (Sun \& Cheng, 2002; Saha \& Cotta, 2008; McIntosh \& Vancov, 2010). Oxidizing agents or acids seem to cause a complete solubilization of hemicellulose and a reduction in lignin content of the treated material, possibly creating hollow spaces within the cellulose matrix that makes the cell walls more accessible to ruminal microbial action (Shefet \& Ben-Ghedalia, 1982). By releasing cellulose and hemicellulose, such chemical treatment increases the forage quality of highly lignified plant material. In fact, ammonium pre-treatment of sorghum stover was reported to increase intake and degradation of sorghum stover in sheep (Ben Salem et al., 1994). This study was undertaken to determine the effects of alkali (ammonium hydroxide) treatment of residual material from grain- and sweet-sorghum production on composition and IVDMD.

\section{Materials and Methods}

\subsection{Location of Study}

The experiment was conducted at the Randolph Research Farm of Virginia State University (VSU) Small Ruminant Research Facility, located in the Tri-Cities area of Central Virginia $\left(37.1^{\circ} \mathrm{N} ; 77.3^{\circ} \mathrm{W}\right)$ at an elevation of $45 \mathrm{~m}$ above sea level.

\subsection{Sorghum Stover}

The study involved the use of stover residue recovered from two sorghum varieties; brown mid rib (BMR), short grain sorghum variety and Dale, a tall sweet sorghum variety. The residue from the two varieties was obtained from ongoing research projects at VSU Agriculture Research Station and included the leaves and stems obtained after the seed or panicle was harvested. The stem and leaves were cut into small pieces and dried to a constant weight in a conventional oven set at $60{ }^{\circ} \mathrm{C}$. The dried Stover residue was ground through a $2 \mathrm{~mm}$ screen in a Willey Mill (Arthur A. Thomas Co., Philadelphia, PA).

Samples of ground stover $(100 \mathrm{~g} \mathrm{DM})$ were placed in plastic bags and water was added to give a $50 \% \mathrm{DM}$. The treatments were (TUN) no ammonium hydroxide, (T00) water only, T50 and T100, 50 and $100 \mathrm{~g} \mathrm{NH} 4 \mathrm{OH}$ per kg residue dry matter respectively. Each treatment was done in triplicates. The bags were immediately closed, the contents mixed thoroughly and allowed to react for seven days at room temperature (21 to $23^{\circ} \mathrm{C}$ ). After a week, all bags were removed and air dried for $48 \mathrm{~h}$.

\subsection{Sample Analyses}

All samples were assayed for dry matter (DM), crude protein (CP), soluble protein (SolProt), acid detergent fiber $(\mathrm{ADF})$, neutral detergent fiber (NDF), neutral detergent insoluble protein (NDIP), acid detergent insoluble/heat damaged protein (ADIPHD), starch, lignin, ash and IVDMD by ANALAB, Division of Agri-King, Inc. 


\subsection{Statistical Analyses}

Data among treatments in composition and in vitro dry matter disappearance were analyzed using the General Linear Model procedure of SAS (2009). The model statement included treatment, variety and treatment $\times$ variety (Interaction) effects. When analysis revealed significant differences among treatment means, the Least Significant Differences $(P \leq 0.05)$ were used to separate means among treatments and varieties.

\section{Results and Discussion}

Chemical composition of the stover residue from the BMR (Short) and Dale (Tall) varieties is given in Table 1. The CP (N X 6.25), NDF and ADF content ranged between 32-50, 389-616, and 255-372 $\mathrm{g} \mathrm{kg}^{-1} \mathrm{DM}$, respectively, and were relatively higher in the BMR than in Dale. The Short variety contained higher ADF, NDF, Lignin and lower IVDM (501 vs $\left.575 \mathrm{~g} \mathrm{~kg}^{-1} \mathrm{DM}\right)$.

Table 1. Chemical composition of residue of two sorghum varieties

\begin{tabular}{ccc}
\hline \multirow{2}{*}{ Item } & \multicolumn{2}{c}{ Variety } \\
\cline { 2 - 3 } & BMR (Short) $\left(\mathrm{g} \mathrm{kg}^{-1} \mathrm{DM}\right)$ & Dale $($ Tall $)\left(\mathrm{g} \mathrm{kg}^{-1} \mathrm{DM}\right)$ \\
\hline DM $^{1}$ & 923.6 & 891.5 \\
OM $^{2}$ & 931.5 & 957.2 \\
$\mathrm{CP}^{-3}$ & 50.3 & 32.4 \\
Solprot $^{4}$ & 222.2 & 224.6 \\
ADIP_HD $^{5}$ & 6.6 & 3.1 \\
ADF $^{6}$ & 372.3 & 255.1 \\
NDF $^{7}$ & 616.3 & 389.2 \\
Lignin & 53.0 & 45.2 \\
Ash & 68.5 & 42.8 \\
Starch & 33.4 & 106.2 \\
IVDMD $^{8}$ & 500.6 & 575.2 \\
\hline
\end{tabular}

${ }^{1} \mathrm{DM}$, Dry matter; ${ }^{2} \mathrm{OM}$, Organic matter; ${ }^{3} \mathrm{CP}$, Crude protein; ${ }^{4}$ Solprot, Soluble protein; ${ }^{5}$ ADIP/HD, Acid detergent insoluble protein or Heat damaged protein; ${ }^{6} \mathrm{ADF}$, Acid detergent fiber; ${ }^{7} \mathrm{NDF}$, Neutral detergent fiber; ${ }^{8}$ IVDMD, In vitro dry matter disappearance.

\subsection{In vitro Dry Matter Disappearance and Crude Protein}

There was no treatment $\times$ variety interaction $(P>0.05)$ in the IVDMD of the sorghum stover residue treated with $\mathrm{NH}_{4} \mathrm{OH}$. Ammonium hydroxide treatment but not its level increased $(P<0.05)$ the mean IVDMD by $25 \%$, from 530 to $660 \mathrm{~g} \mathrm{~kg}^{-1} \mathrm{DM}$ (Figures 1a and 1b). The IVDMD of the residue from the two varieties was affected differently by the levels of $\mathrm{NH}_{4} \mathrm{OH}$ treatment. Ammoniation increased IVDMD of the residue in the tall variety $14 \%$ over the short variety (550 to $\left.630 \mathrm{~g} \mathrm{~kg}^{-1} \mathrm{DM}\right)$. The tall variety appears to be more digestible compared to the short variety (635 vs $550 \mathrm{~g} \mathrm{~kg}^{-1} \mathrm{DM}$ ). The increase in IVDMD agrees with those of Hartley and Jones (1978) and Soleiman et al. (1979) although the increments obtained in this study were slightly higher.

Ammonium hydroxide treatment increased CP (N X 6.25) in sorghum residue in both varieties $(P<0.05)$ but did not affect $\mathrm{CP}$ similarly across varieties and treatments as indicated by treatment $\times$ variety interaction $(P<0.05)$ (Table 2). Untreated sorghum residue CP in the short variety was $50 \mathrm{~g} \mathrm{~kg}^{-1} \mathrm{DM}$ where as in the tall variety it was $32 \mathrm{~g} \mathrm{~kg}^{-1} \mathrm{DM}$ (Table 2). When it was treated with $50 \mathrm{~g} \mathrm{~kg}^{-1} \mathrm{DM} \mathrm{NH}_{4} \mathrm{OH}$, the $\mathrm{CP}$ increased two folds in the short variety and three fold in the tall variety. Treatment with $100 \mathrm{~g} \mathrm{~kg}^{-1} \mathrm{DM} \mathrm{NH} \mathrm{H}_{4} \mathrm{OH}$ further increased the $\mathrm{CP}$ three fold in the short variety from 50 to 133 and four fold in the tall variety from 32 to $138 \mathrm{~g} \mathrm{~kg}^{-1} \mathrm{DM}$. Similar effects of increased $\mathrm{CP}$ in poor quality forages as a result of ammoniation were reported in wheat straw (Soleiman et al, 1979), Barley straw (Graham \& Aman, 1984), limpograss (Brown et al., 1987), and tall fescue straw (Kallenbach et al., 2006). The increased CP observed can be explained by both the nitrogen added and the ammonolysis reaction between the carbohydrates and the alkali as previously reported (Dryden \& Kempton, 1983; Alibez et al., 1984; Mason et al., 1990b; Kondo et al., 1992). 
There was no treatment $\times$ variety interaction $(P>0.05)$ in the soluble protein (Solprot) which is the fraction of protein rapidly degraded to ammonia in the rumen. There was, however, varietal as well as treatment difference $(P<0.05)$ in soluble protein (Figures $1 \mathrm{c}$ and $1 \mathrm{~d})$. The tall variety contained more soluble protein compared to the short (42.56 vs $\left.33.57 \mathrm{~g} \mathrm{~kg}^{-1} \mathrm{DM}\right)$. Treatment with $\mathrm{NH}_{4} \mathrm{OH}$ at both levels resulted in similar soluble protein content compared to the untreated residue $\left(\mathrm{T} 50=58.35\right.$; T100 $\left.=63.01 \mathrm{~g} \mathrm{~kg}^{-1} \mathrm{DM}\right)$ suggesting that the higher treatment may not have beneficial effects over that of the lower level.
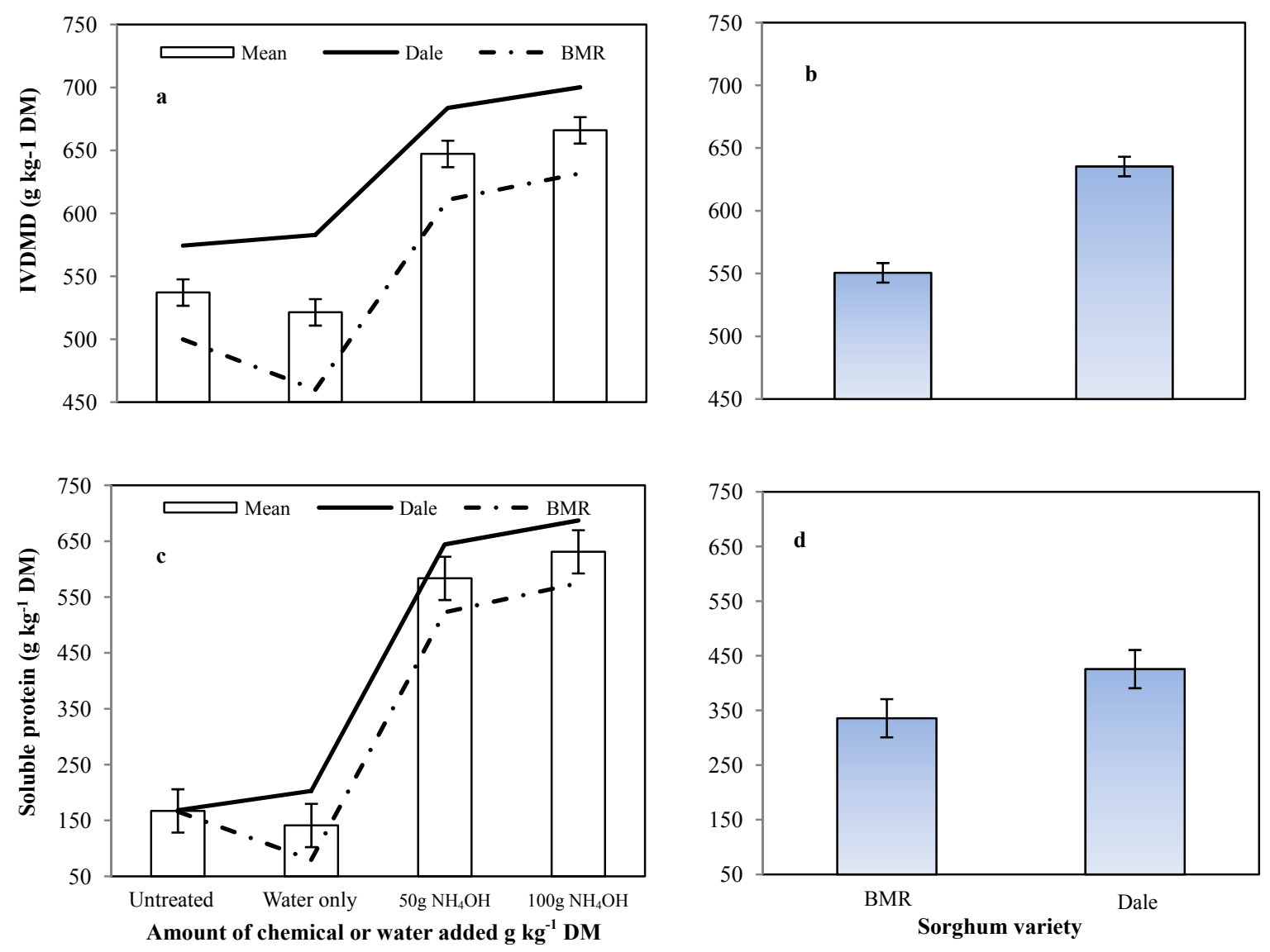

Figure 1. In vitro dry matter digestibility IVDMD and soluble protein as affected by treatments (a) and (c) and by sorghum variety (b) and (d), respectively

Acid detergent insoluble/heat damaged protein (ADIPHD) is estimated by the acid detergent insoluble nitrogen in the analysis. There was no treatment $\mathrm{x}$ variety interaction $(P>0.05)$ in heat damaged protein content. Ammonium hydroxide treatment did not change $(P>0.05)$ the heat damaged protein content of the residue (Figures $2 \mathrm{c}$ and $2 \mathrm{~d})$. The tall variety has lower $(P<0.05)$ HDP compared to the short variety $\left(3.6 \mathrm{vs} 7.8 \mathrm{~g} \mathrm{~kg}^{-1}\right.$ $\mathrm{DM})$.

\subsection{Fiber Fractions}

The concentrations of various fiber fractions $\left(\mathrm{g} / 100 \mathrm{~g}\right.$ DM) due to $\mathrm{NH}_{4} \mathrm{OH}$ treatment are shown in Table 3 . There was no treatment $\mathrm{x}$ variety interaction $(P=0.94)$. The levels of $\mathrm{NH}_{4} \mathrm{OH}$ treatment did not affect $(P=0.59)$ the NDF content of the sorghum stover residue (Table 3). There was difference in NDF content between the varieties. Averaged across varieties, the short variety has higher $(P<0.05)$ NDF content $\left(597.6 \mathrm{~g} \mathrm{~kg}^{-1}\right)$ than the tall variety $\left(383.2 \mathrm{~g} \mathrm{~kg}^{-1}\right)$ (Table 3$)$. There was no interaction between treatment and variety $(P>0.05)$ in the ADF fraction of the stover residue. Treatment with $\mathrm{NH}_{4} \mathrm{OH}$ did not affect the ADF content $(P>0.05)$ (Table 3). BMR had higher ADF $(P<0.05)$ than Dale at both $\mathrm{NH}_{4} \mathrm{OH}$ treatment levels. 
Table 2. Composition of ammonium hydroxide treated sorghum residues

\begin{tabular}{|c|c|c|c|c|}
\hline Variety & Level of $\mathrm{NH}_{4} \mathrm{OH}^{1}$ & $\mathrm{CP}^{2}$ & NDIP $^{3}$ & Starch \\
\hline \multirow{3}{*}{ BMR (Short) } & TUN (Water \& NH4OH Untreated) & $50.3 \mathrm{e}$ & $28.1 \mathrm{~b}$ & $33.4 \mathrm{f}$ \\
\hline & T00 (Water only treated) & $49.3 \mathrm{e}$ & $25.7 \mathrm{bc}$ & $11.3 \mathrm{~g}$ \\
\hline & T05 (5 $\left.\mathrm{g} \mathrm{NH}_{4} \mathrm{OH} \mathrm{kg}{ }^{-1} \mathrm{DM}\right)$ & $108.4 \mathrm{c}$ & $35.9 \mathrm{a}$ & $103.0 \mathrm{~d}$ \\
\hline \multirow{6}{*}{ Dale (Tall) } & $\mathrm{T} 10\left(10 \mathrm{~g} \mathrm{NH}_{4} \mathrm{OH} \mathrm{kg}{ }^{-1} \mathrm{DM}\right)$ & $133.8 \mathrm{~b}$ & $35.7 \mathrm{a}$ & $121.2 \mathrm{c}$ \\
\hline & TUN (Water \& $\mathrm{NH}_{4} \mathrm{OH}$ Untreated) & $32.4 \mathrm{f}$ & $23.6 \mathrm{c}$ & $106.2 \mathrm{dc}$ \\
\hline & T00 (Water only treated) & $32.2 \mathrm{f}$ & $24.3 \mathrm{c}$ & $88.2 \mathrm{e}$ \\
\hline & $\mathrm{T} 05\left(5 \mathrm{~g} \mathrm{NH}_{4} \mathrm{OH} \mathrm{kg}{ }^{-1} \mathrm{DM}\right)$ & $103.9 d$ & $27.7 \mathrm{~b}$ & $144.9 \mathrm{~b}$ \\
\hline & $\mathrm{T} 10\left(10 \mathrm{~g} \mathrm{NH}_{4} \mathrm{OH} \mathrm{kg}{ }^{-1} \mathrm{DM}\right)$ & $138.2 \mathrm{a}$ & $25.5 \mathrm{bc}$ & $158.9 \mathrm{a}$ \\
\hline & & \multicolumn{3}{|c|}{----------------- Probability ------------ } \\
\hline Treatment & & 0.0001 & 0.0001 & 0.0001 \\
\hline Variety & & 0.0001 & 0.0001 & 0.0001 \\
\hline \multicolumn{2}{|c|}{ Treatment $\mathrm{x}$ Variety } & 0.0001 & 0.0044 & 0.0008 \\
\hline
\end{tabular}

${ }^{1} \mathrm{NH}_{4} \mathrm{OH}$ Ammonium hydroxide; ${ }^{2} \mathrm{CP}$ Crude protein; ${ }^{3}$ NDIP Neutral detergent insoluble protein; ${ }^{4}$ Values in the same column followed by different letters differ significantly $(P<0.05)$.

Ammonium hydroxide treatment decreased lignin content in both varieties $(P<0.05)$ but the reduction was not similar across varieties and treatments as indicated by treatment $\mathrm{x}$ variety interaction $(P<0.05)$ (Table 3$)$. The lignin content of the $\mathrm{NH}_{4} \mathrm{OH}$ treated residue in the short variety was reduced by $40 \%$ (from 53 to $32 \mathrm{~g} \mathrm{~kg}^{-1} \mathrm{DM}$ ) and by $33 \%$ in the tall variety (from 45 to $30 \mathrm{~g} \mathrm{~kg}^{-1} \mathrm{DM}$ ).
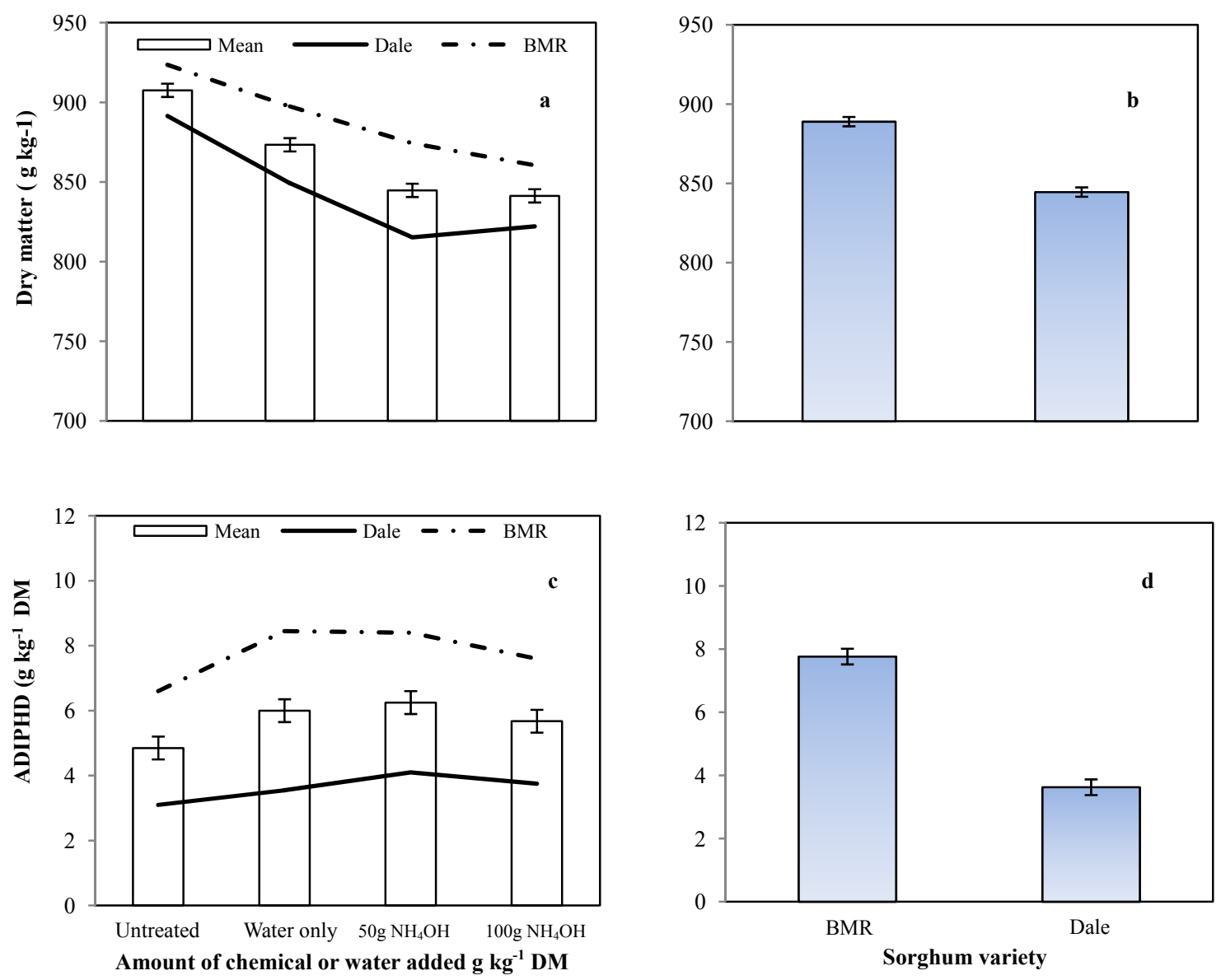

Figure 2. Dry matter ( $\left.\mathrm{DM} \mathrm{g} \mathrm{kg}^{-1}\right)$ and acid detergent insoluble or heat damaged protein as affected by treatments (a) and (b) and by sorghum variety (c) and (d), respectively 
Table 3 composition of ammonium hydroxide treated sorghum residues

\begin{tabular}{|c|c|c|c|c|c|}
\hline Variety & Level of $\mathrm{NH}_{4} \mathrm{OH}^{1}$ & $\mathrm{ADF}^{2}$ & $\mathrm{NDF}^{3}$ & Lignin & Ash \\
\hline BMR & Water \& $\mathrm{NH}_{4} \mathrm{OH}$ Untreated & $372.3 \mathrm{a}$ & $616.3 \mathrm{a}$ & $53.0 \mathrm{a}$ & $49.6 \mathrm{~d}$ \\
\hline \multirow[t]{3}{*}{ (Shorty) } & T00 (Water only treated) & $383.7 \mathrm{a}$ & $590.7 \mathrm{a}$ & $57.3 \mathrm{a}$ & $68.5 \mathrm{c}$ \\
\hline & $\mathrm{T} 05\left(5 \mathrm{~g} \mathrm{NH}_{4} \mathrm{OH} \mathrm{kg}^{-1} \mathrm{DM}\right)$ & $370.5 \mathrm{a}$ & $585.9 \mathrm{a}$ & $40.2 \mathrm{c}$ & $75.5 b$ \\
\hline & $\mathrm{T} 10\left(10 \mathrm{~g} \mathrm{NH}_{4} \mathrm{OH} \mathrm{kg}{ }^{-1} \mathrm{DM}\right)$ & $369.9 \mathrm{a}$ & $597.6 \mathrm{a}$ & $32.1 \mathrm{de}$ & $89.1 \mathrm{a}$ \\
\hline Dale & Water \& $\mathrm{NH}_{4} \mathrm{OH}$ Untreated & $255.1 \mathrm{~b}$ & $399.2 b$ & $45.2 \mathrm{~b}$ & $42.8 \mathrm{e}$ \\
\hline \multirow[t]{4}{*}{ (Tall) } & T00 (Water only treated) & $265.8 \mathrm{~b}$ & $381.1 \mathrm{~b}$ & $40.9 \mathrm{bc}$ & $70.0 \mathrm{bc}$ \\
\hline & $\mathrm{T} 05\left(5 \mathrm{~g} \mathrm{NH}_{4} \mathrm{OH} \mathrm{kg}{ }^{-1} \mathrm{DM}\right)$ & $265.7 b$ & $373.7 \mathrm{~b}$ & $35.1 \mathrm{~d}$ & $75.2 \mathrm{bc}$ \\
\hline & $\mathrm{T} 10\left(10 \mathrm{~g} \mathrm{NH}_{4} \mathrm{OH} \mathrm{kg}{ }^{-1} \mathrm{DM}\right)$ & $264.3 b$ & $389.0 \mathrm{~b}$ & $30.3 \mathrm{e}$ & $90.8 \mathrm{a}$ \\
\hline & & ------- & ----- P & ability -- & - \\
\hline \multicolumn{2}{|l|}{ Treatment } & 0.0852 & 0.5929 & 0.0001 & 0.0452 \\
\hline \multicolumn{2}{|l|}{ Variety } & 0.0122 & 0.0001 & 0.0001 & 0.0001 \\
\hline \multicolumn{2}{|c|}{ Treatment $\mathrm{x}$ Variety } & 0.1110 & 0.9401 & 0.0072 & 0.1081 \\
\hline
\end{tabular}

${ }^{1} \mathrm{NH}_{4} \mathrm{OH}$ Ammonium hydroxide; ${ }^{2}$ ADF Acid detergent fiber; ${ }^{3}$ NDF Neutral detergent fiber; ${ }^{4}$ Values in the same column followed by different letters differ significantly $(P<0.05)$.

\section{Conclusions}

Ammonium hydroxide treatment was an effective treatment to increase $\mathrm{CP}$ concentrations in sorghum stover residue and improve its usefulness as livestock feed. The IVDMD of this material was relatively low and differed between the residues of the two sorghum varieties. Treatment with $\mathrm{NH}_{4} \mathrm{OH}$ increased IVDMD by reducing lignin content but increasing the fiber. There was also considerable diversity in the varieties in the fiber and lignin concentrations. For this reason researchers may be able to exploit the germplasm to develop cultivars with improved feed characteristics while maintaining traits for other uses (e.g., dry matter production, sugar content, lignocellulosic conversion, etc.). Subsequent studies should focus on evaluating other alkali and even acids for other feedstock (biofuel and livestock feed) traits. The development of more economical and safe procedures which improves digestibility of the structural cell wall components would be very beneficial for improving the nutritive value of low quality roughages. Use of crop residue as feedstock in bioethanol production can also be improved along the same lines for nutritional values.

\section{Acknowledgements}

This study was supported in part by a grant NSF HBCU-UP and Virginia State University Agriculture Research Station. Contribution of Virginia State University, Agricultural Research Station, Journal Article Series number 318.

\section{References}

Alibez, X., Mufioz, F., \& Faci, R. (1984). Anhydrous ammonia treated cereal straw for animal feeding. Some results from the Mediterranean area. Anim. Feed Sci. Technol., 10, 239-246. http://dx.doi.org/10.1016/0377-8401(84)90013-0

Amjed, M., Jung, M. G., \& Donker, J. D. (1992). Effect of alkaline hydrogen peroxide treatment on cell wall composition and digestion kinetics of sugarcane residues and wheat straw. J. Anim. Sci., 70, 2877-2884. Retrieved from http//www.journalofanimalscience.org/content/70/9/2877

Ben Salem, H., Nefzaoui, A., \& Rokbani, N. (1994). Upgrading of sorghum stover with anhydrous ammonia or urea treatments. Animal Feed Sci. and Tech., 48, 15-26. http://dx.doi.org/10.1016/0377-8401(84)90022-1

Ben-Ghedalia, D. Shefet, G., \& Miron, J. (1980). Effect of ozone and ammonium hydroxide treatments on the composition and in vitro digestibility of cotton straw. J. Sci. Food Agric., 31, 1337-1342.

Ben-Ghedalia, D., \& Miron, J. (1981). Effect of sodium hydroxide, ozone and sulphur dioxide on the composition and in vitro digestibility of wheat straw. J. Sci. Food Agric., 32, 224-228.

Ben-Ghedalia, D., \& Miron, J. (1984). The response of wheat straw varieties to mild sulphur dioxide treatment. 
Anim. Feed Sci. Technol., 10, 269-276. http://dx.doi.org/10.1002/jsfa.2740320304

Bolsen, K. K., Grimes, C., \& Riley, J. G. (1977). Milo stover in rations for growing heifers and lambs. J. Anim. Sci., 45, 377-384. Retrieved from http//www.journalofanimalscience.org/content/45/2/377

Brown, W. F., Phillips, J. D., \& Jones, D. B. (1987). Ammoniation or cane molasses supplementation of low quality forages. J. Anim. Sci., 64, 1205-1214.

Bunting, L. C., Richardson, C. R., \& Tock, R. W. (1984). Digestibility of ozone treated sorghum stover by ruminants. J. Sci. Food Agric., 102, 147-150.

Delgado, C., Rosegrant, M., Steinfeld, H., Ehui, S., \& Courboi, C. (1999). Livestock to 2020 - The Next Food Revolution. Food, Agriculture and the Environment Discussion Paper 28. IFPRI, Washington D.C.

Doyle, P. T., Devendra, C., \& Pearce, G. R. (1986). Rice Straw as a Feed for Ruminants (pp. 22-49). IDP, Canberra.

Dryden, G., \& Kempton, T. J. (1983). Digestion of organic matter and nitrogen in ammoniated barley straw. Anim. Feed Sci. Technol., 7, 45-51. http://dx.doi.org/10.1016/0377-8401(82)90035-9

Ernest, R. K., \& Buffington, L. E. (1981). Crop residue. In T. A. McClure, E. S. Lipinsky (Ed.), Handbook of bisolar research materials. Boca Raton, FL7 CRC Press.

Goto, M., Yokoe, Y., Takabe, K., Nisikawa, S., \& Morita, O. (1993). Effects of gaseous ammonia on chemical and structural features of cell walls in spring barley straw. Animal Feed Sci. and Tech., 40, 207-221.

Hartley, R. D., \& Jones, E. C. (1978). Effect of aqueous ammonia and other alkalis on the in vitro digestibility of barley straw. J. Sci. Food Agr., 29, 92-98. http://dx.doi.org/10.1002/jsfa.2740290204

Hons, F. M., Moresco, R. F., Wiedenfield., R. P., \& Cothren, J. T. (1986). Applied nitrogen and phosphorous effects on yield and nutrient uptake by high energy sorghum produced for grain and biomass. Agron. J., 78, 1069-1078. http://dx.doi.org/10.2134/agronj1986.00021962007800060026x

Houx III, J. H., Craig, A. R., \& Felix, B. F. (2013). Evaluation of sweet sorghum bagasse as an alternative livestock feed. Crop Sci., 53, 1784-1790. http://dx.doi.org/10.2135/cropsci2012.03.0190

Jackson, M. G. (1977). Review article: The alkali treatment of straw. Anim. Feed Sci. Technol., 2, $105-130$. http://dx.doi.org/10.1016/0377-8401(77)90013-X

Kallenbach, R. L., Roberts, C. A., Lock, T. R., Keisler, D. H., Ellersieck, M. R., \& Rottinghaus, G. E. (2006). Performance of steers fed ammoniated straw from tall fescue seed fields. Forage Grazing lands. http://dx.doi.org/10.1094/FG-2006-0113-01-RS

Kerley, M. S., Fahey, G. C., Berger, L. L., Merchen, N. R., \& Gould, J. M. (1987). Effects of treating wheat straw with $\mathrm{pH}$-regulated solutions of alkaline hydrogen peroxide on nutrient digestion by sheep. J. Dairy Sci., 70, 2078-2084. http://dx.doi.org/10.3168/jds.S0022-0302(87)80256-4

Klopfenstein, T. J. (1978). Chemical treatment of crop residues. J. Anim. Sci., 46, 841-848. Retrieved from http//www.journalofanimalscience.org/content/46/3/841

Kondo, T., Ohshita, T., \& Kyuma, T. (1992). Comparison of characteristics of soluble lignins from untreated and ammonia-treated wheat straw. Anim. Feed Sci. Technol., 39, 253-263.

Mason, V. C., Cook, J. E., Dhanoa, M. S., Keene, A. S., Hoadley, C. J., \& Hartley, R. D. (1990b). Chemical composition, digestibility in vitro and biodegradability of grass hays oven-treated with different amounts of ammonia. Anim. Feed Sci. Technol., 29, 237-249.

Mason, V. C., Dhanoa, M. S., Hartley, R. D., \& Keene, A. S. (1990a). Relationships between chemical composition, digestibility in vitro and cell wall degradability of wheat straw treated withdifferent amounts of ammonia and water at elevated temperature. Anim. Feed Sci. Technol., 27, 293-306.

McIntosh, S., \& Vancov, T. (2010). Enhance enzyme saccharification of Sorghum bicolor straw using dilute alkali pretreatment. Bioresour. Tech., 17, 6718-6727.

Nicholson, J. W. G. (1984). Digetibility, nutritive value and feed intake. In F. Sundstøl \& E. Owens (Eds.), Straw and other fibrous by-products as feed (pp 340-367). Elsevier, Armsterdam.

Putnam, D. H., Lueschen, W. E., Kanne, B. K., \& Hoverstad T. R. (1991). A comparison of sweet sorghum cultivars and maize for ethanol production. J. Prod. Agric., 4, 377-381.

Rooney, W. L., Blumenthal, J., Bean B., \& Mullet, J. E. (2007). Designing sweet sorghum as a dedicated 
bioenergy feedstock. Biof. Bioprod. Bioref., 1, 147-157. http://dx.doi.org/10.1002/bbb.15

Rounds, W., \& Klopfenstein, T. J. (1974). Chemicals for treating crop residues. J. Anim. Sci., 39, 251.

Saha, B. C., \& Cotta, M. A. (2008). Lime pretreatment, enzymatic saccharification and fermentation of rice hulls to ethanol. Biomass Bioenergy, 3, 971-977.

SAS Institute. (2009). The SAS system for Windows. Release 9.3. SAS Inst., Cary, NC.

Shefet, G., \& Ben-Ghedalia, D. (1982). Effect of ozone and sodium treatments on the degradability of cotton straw monosaccharides by rumen microorganisms. Eur. J. Appl. Microbiol. Technol., 15, 47.

Smith, G. A., Bagby, M. O., Lewellan, R. T., Doney, D. L., Moore, P. H., Hills, F. J., Campbell, L. G., ... Freeman, K. (1987). Evaluation of sweet sorghum for fermentable sugar production potential. Crop Sci., 27, 788-793. http://dx.doi.org/10.2135/cropsci1987.0011183X002700040037x

Soleiman, S. G., Horn, G. W., \& Owens, F. N. (1979). Ammonium hydroxide treatment of wheat straw. J. Anim. Sci., 49, 802-808. Retrieved from http//www.journalofanimalscience.org/content/49/3/802

Sultan, J. I., Fluharty, F. L., Firkins, J. L., \& Loerch, S. C. (1992). Effects of supplemental protein source and alkaline hydrogen peroxide treatment of wheat straw on site of nutrient digestion and flow of nitrogenous compounds to the duodenum of steers. J. Anim. Sci., 70, 3909-3915. Retrieved from $\mathrm{http} / / \mathrm{www}$.journalofanimalscience.org/content/70/12/3909

Sun, F. B., \& Chen, H. Z. (2007). Evaluation of enzymatic hydrolysis of wheat straw treated by atmospheric glycerol autocatalysis. J. of Chem. Technol and Biotechnol., 82, 1039-1044.

Sundstol, F. (1984). Ammonia treatment of straw: methods for treatment and feeding experience in Norway. Anim. Feed Sci. Technol., 10, 173-187.

USDA, National Agricultural Statistics Service. (2013). U.S. Sorghum Acres. Retrieved May, 2014, from http://www.usda.gov/nass/aggraphs/sorgac.htm

Waiss, A. C., \& Guggolz, J. (1972). Improving digestibility of straw for ruminants feed by aqueous ammonia. $J$. Anim. Sci., 35, 109-112.

Ward, J. K., Perry, L. J. Jr., Smith, D. H., \& Schmitz, J. T. (1979). Forage composition and utilization of grain sorghum residue by beef cows. Journal of Animal Science, 48, 919-925. Retrieved from http//www.journalofanimalscience.org/content/48/4/919

Youngquist, J. B., Carter, D. C., \& Clegg, M. D. (1990). Grain and forage yield and stover quality of sorghum and millet in low rainfall environments. Exp. Agr., 26, 229-286.

\section{Copyrights}

Copyright for this article is retained by the author(s), with first publication rights granted to the journal.

This is an open-access article distributed under the terms and conditions of the Creative Commons Attribution license (http://creativecommons.org/licenses/by/3.0/). 